SF 51

. D3 
LIBRARY OF CONGRESS |||||||||||||||||||||||||||||||||||||||||||| 00028235331

Hollinger Corp. $\mathrm{pH} 8.5$ 


\title{
The Animal Industry of the
} South--Past, Present, Future

\author{
illien edock \\ By Dr. W. H. Dalrymple
}

Professor of Veterinary Science, Louisiana State

University and A. \& M. College

Cut-Over Land Conference of the South April 11, 12, 13, 1917, New Orleans, La.

cnew Orleans, Ca, 1917 



\section{The Animal Industry of the South-Past, Present and Future}

\section{By Dr. W. H. Dalrymple Professor of Veterinary Science, Louisiana State University and A. \& M. College}

As regards the past of animal industry in the South, I do not believe it would aid us much at this time to dwell to any extent on the conditions that are behind us, unless it should be to utilize our remembrance of them, along with what we know of the present, to help us build more solidly for the future.

There is one thought, however, which appeals to me very strongly, viz., that if we expect to make the most out of our great agricultural and live stock possibilities in the future we Stop Playing With Agriculture will have to consider and treat them in a much more serious manner than has been the case in the past, or as some seem to view them even at the present time.

Or, to quote a recent remark made by a prominent British agriculturist, as he views matters at the present time in that country, and which, in some degree at least, may apply to us, viz., "We can play with politics, with industry, with law, and even with the consuming fires of civilized (?) warfare, but if we value the future of our country; and of our race, we cannot any longer afford to play with agriculture."

The great cattle ranges of the West are rapidly being placed under cultivation to meet the demands of an ever-increasing population, both natural and through immigration, and which may be largely added to after the world is again at peace, who have to be provided with occupations, and whose stomachs have to be filled. In fact, one of the greatest economic problems confront- 
ing us at the present moment is, how to increase the producing capacity of our soils, and extend our cultivable areas to the utmost, even to our home gardens and backyards, not only to keep pace with our present-day requirements under normal conditions, but to meet a most abnormal state occasioned by our participa-

World Demands More Food

The South as the Nation's Hope tion in a world's conflict. The call for the highest standard of efficiency in the production and conservation of food does not come only to the American farmer, but the cry today comes from everywhere, for the mobilization of the world's agricultural resources, so that the people of different continents may not suffer for lack of the necessities of life.

For some time, however, we have been brought face to face with the problem of the high cost of living, even before the present international crisis became so acute, and we have heard of many attempts, theoretical and otherwise, to reach an intelligent solution. Might we not, with appropriateness, ask ourselves the question: If agricultural conditions in the South had, all of these years, been in keeping with her possibilities, in the production of the daily necessities of our people, in the matter of food supplies, both animal and vegetable, would conditions, as we find them today, have been likely, even with the world in a state of war? I am inclined to think not!

I believe, however, that the South will, before many decades have passed, be the great stock-raising section of the country, more particularly the meat-producing animals, and will, after we stop "playing with agriculture," be able to furnish both food for our people and enough, and to spare, of the feed crops necessary to develop and maintain a largely increased animal population. In short, it is our belief that, ultimately, the South will have to come to the rescue in preventing the risk of any serious break in the equilibrium of our food supply, should that ever occur; and I also believe that she will be fully equal to the occasion.

Up to the present, however, and in a general way, our Southern country has not even approached the point of maximum production, either in food crops, or in the number or quality of our live stock, to be able to successfully compete with other more advanced sections in the great metropolitan markets. And even if she had, especially in her cattle production, there are considerable areas from which her animals would be excluded from such markets because of Federal restrictions imposed on 
account of the presence of that most expensive pest, the cattle tick.

It is gratifying to know, however, that total extermination of this parasite is a question of only a few more years of cooperative effort; and its accomplishment lies at the very founThe Tick a Disappearing dation of our general agricultural prosperity in the future.

True, the cattle tick has militated very seriously against our progress in the production of improved cattle; but our chief obstruction, which I believe is now generally conceded, has been our almost universal system of single-cropping.

Doubtless, and on account of the world-wide need for cotton, this system has, temporarily if you will, brought large returns to our people.

But, under such a system, in which every other necessity of the farm and home has had to be purchased and paid for out of those returns, has the fertility of our soils been increased; has it increased their power to produce, or otherwise enhanced their value? I think not!

On the other hand, had our general farming system been more along the lines of diversification and crop rotation, including cotton, necessarily, and, of course, live stock, and with intelligent fertilization, with increased yields of both cash crops and those for consumption by our farm animals, and with a sufficiency of the latter crops to bring to prime market condition the meat-producing animals, such as cattle, sheep and hogs, and through them to market the farm feeds and forages at enhanced values, conditions might have assumed a very different aspect. In short, had such conditions prevailed, these many years, and with the South on equal footing with other sections of the country, with reference to our great markets, is it reasonable to presume, even under present abnormal conditions, that the cry about high-priced necessities would have had to be so vigorously proclaimed all over the land?

But up to the present time it may be said that the South has Now is Time scarcely been reckoned as among the purveyors of the nation's for South to food supply. Act

This condition, however, has got to change; in fact, is doing so gradually, if not as rapidly as perhaps one could wish. At the same time, it is our humble, but candid, opinion that by taking full and immediate advantage of present opportunities, 
South a Land of Infinite Possibilities.

and with the further possibilities incident to the utilization of our extensive areas of unused and uncultivated land, the South, in a reasonably short period of time, should not only be able to clothe our people with her cotton and wool products, but should have a large share in the feeding of them with the cereals and their by-products, and with toothsome meat from her well-bred, well-fed, and high-grade cattle, hogs and sheep.

We occasionally hear the remark that the South is a splendid "poor man's country," on account of the ease with which a living may be made.

Such a statement might be construed into a reflection upon our past, or, in some cases, our present, farming methods. And yet it is a most eloquent indorsement of the fertility of our soils that they have been able to even support such methods. But what would be the result did our lands receive the treatment which would be bestowed upon them by a more intelligent system of husbandry; where the farmer made a more thorough study of his profession or calling; made a business of farming rather than a means to eke out a mere existence; who built up his soils; aimed at maximum production; varied his products, both in field crops and in live stock; kept up with the markets; rotated his crops, and strived to produce nothing but the very best his land would yield, and that the market demanded? To try to even picture to ourselves the prosperity of our Southern country under such conditions would be practically impossible.

And, yet, it is just such conditions that we must aim to realize, if we may hope to obtain to the full the results which our opportunities and possibilities have placed within our reach.

Live stock is an absolute necessity on every well-regulated farm, not merely out of sentiment, as some still seem to think, but as a necessary adjunct to the business, that can be employed The Necessity as local factories, if you will, through which the cheaper raw for Live Stock materials grown may be converted into high-priced finished products, in the form of high-class beef, mutton, pork, etc., which can be marketed "on the hoof."

In fact, one could scarcely imagine a more inharmonious enterprise, or a more discordant undertaking, than an otherwise modern farm holding without its due quota of improved live stock of different varieties. 
And yet, even today, it is not an uncommon sight to see nondescript animals occupying valuable space, on many of our farming properties, that are forced to eke out a precarious existence, as best they can, or die in the effort.

We all must admit, however, that the climate of the South is ideal for live stock husbandry, in all of its departments, from the growing of the food crops to the finishing of the product for market.

Forage crops, in great variety, grow with a luxuriance that would "tickle the palate" and "whet the appetite" of the most fastidious and epicurean of our herbivorous animals.

Among the legumes, it is only necessary to mention alfalfa, Forage Crops which may be used for grazing, for soiling, or for hay. Les- Abundant pedeza, our great Southern clover, which makes a most valuable hay, and enhances the value of our pasture when mixed with our native grasses. The cow pea, the soy bean, the velvet bean, the clovers and some of the vetches, etc., all furnish abundant and nutritious food for live stock.

In short, the South has, or can have, a superabundance, both as to quantity and variety, of these most valuable nitrogengathering, soil-improving, and protein-producing forages, so important for the upbuilding and maintenance of soil fertility, as well as the nutrition of animal life on the farm.

In some sections of the South pasturage may be secured practically the year round by sowing almost any of the small cereals as catch crops, after the staple crops have been harvested, which yield abundantly during the fall and winter months, and furnish succulent food at a season of the year when such is in greatest need.

Silage crops, also, in addition to corn, such as sorghum, etc., Many Useful and root crops of different varieties, produce with great abun-By-Products dance, and may be used to supply excellent succulent feed for cattle, hogs and sheep, after ordinary pasturage has been depleted by the summer's grazing.

But while that which we have enumerated might appear as more than sufficient to meet all practical needs in the matter of live stock feed production, it is by no means all. In addition, there are the important by-products from our cotton fields; and in some parts of the South, those from our rice industry, and from our sugar cane fields and factories. 
With such possibilities, then, in our feed production, our abundance in cereal crops, our many nutritious hays, and other roughage supplies, our winter pasture crops and natural grazing, although much of the latter is yet to be availed of, and in the rich concentrates in the by-products of our cotton, rice and sugar, if the future of stock raising in the South should not appear bright, even to the most casual observer, one is inclined to wonder where else he would go to satisfy his desires in that branch of husbandry.

That all varieties of farm animals do well in the South, it is only necessary to state that all of the principal breeds, and kinds, are already represented, including horses and mules, beef and dairy cattle, hogs and sheep. And not only so, but each has its organizations, in the different states, specially devoted to improvement and greater development of the breeds.

Legislation Fosters Live Stock Raising

\section{Providing} Markets for Live Stock

In addition to the increasing interest being displayed in our live stock production, most, if not all, of the Southern states have taken steps to protect, from the ravages of fatal animal diseases, this important industry. I refer to the enactment, by the different states, of suitable live stock sanitary legislation, and the creation or appointment of boards or commissions to see that it is carried into effect.

Such legislation not only affords protection to the live stock interests of a state, but it gives encouragement to prospective immigrants who expect to make the production of live stock a feature of their farm practice.

There is one very important project, vitally connected with the live stock business, which should not be overlooked in these remarks.

Hitherto, one of the chief drawbacks to the live stock industry, especially in the more southerly states, has been the inaccessibility of the best markets, which has militated considerably against the more profitable disposal of stock, and, necessarily, has discouraged many producers.

This unfortunate state of affairs will very shortly be corrected, however, by the erection and establishment of a large packing plant in the city of New Orleans, which will be operated by the enterprising firm of Morris \& Company.

Such a plant will not only care for a large amount of our surplus stock, but will afford an immense stimulus to greater 
and better production on the part of our people; and we trust will prove entirely profitable to those responsible for the establishment of the new and important enterprise.

I believe all of us must be convinced of the South's unexcelled possibilities in live stock production, of which many of Every Facility Available our people have already taken advantage, with profit to themselves.

We already have an abundance of food materials for animals that would surprise even a Northern or Western stockman, and these are capable of large increase.

We have broad acres of unoccupied fertile lands which simply await the touch of the intelligent husbandman in order to spring into full fruition, and add more wealth and prosperity to our Southern country.

We have representatives of almost every breed and variety of live stock, and an increasing interest constantly being manifested in their greater development.

We have adequate legislation, in practically all of the Southern states, to afford protection against the fatal diseases to which farm animals are susceptible, and which gives encouragement to those engaged in the industry.

We have our State Boards of Agriculture to look after and foster the industry from the standpoint of the state.

We have our State Colleges of Agriculture and our Experiment Stations, and our various branches of Agricultural Extension Service, all bending their efforts to educate and inform our citizens, and encourage and increase interest in this great work.

In short, we not only have the materials to work with, but, in addition, various and important agencies laboring, in an educational way, for the good of the cause; and which are being more and more taken advantage of by our people, and through which advancement is being made.

And we now have one of the most valuable aids to the stock grower in the development of his industry, viz., the privilege of Cheap Money the use of money, which he may obtain on reasonable terms, through the medium of the recently established Federal Farm Loan Banks.

One would naturally imagine, therefore, that all of the needs of the South had already been amply provided, and that nothing more was necessary but to go ahead and prosper; and in a meas- 
Present

Encouraging and Future Bright

ure that is quite true. However, while possession of the raw material is of the first importance, we cannot expect to make the most out of it unless we intelligently employ the appropriate tools or machinery through which to bring it to a state of perfection in the finished product. And so it is with our possibilities; they are not going to benefit us as they should unless we use every effort, and take advantage of every opportunity, to develop them to their highest state of perfection.

In emphasizing one or two of our most important needs, as I see them, I will say, in the first place, that we must double our efforts to wipe the cattle tick from off the map of the Southern states. This is a fundamental necessity in connection with the future success of our cattle industry at least, and that is perhaps the most important.

In the second place, we need more and better live stock through which to market our food crops, and help increase and maintain the fertility of our lands; and we need our own people to devote more time and study to the rational and business sides of animal husbandry and general farming.

In the third place, we need an open market, anywhere and everywhere, and at all times, especially for our cattle, which will depend solely, however, upon the total extermination of the cattle tick from the Southern states, and upon which, likewise, depends the improvement of our cattle, through the influence of improved animals, particularly males, that can then be imported from the best herds of the country; and

In the fourth place, we need more immigration of the desirable, intelligent and industrious farmer-stockman class, whose life and business experience have hitherto been devoted to the branches of stock raising and general agriculture, which we believe the South stands in greatest need of, at the present time, for her general agricultural upbuilding.

Good object lessons are, in great measure, what we require; and this is, I believe, the kind of help we need, and want, to assist us develop our great natural resources, and, as we all believe, our unparalleled possibilities.

In summing up, therefore, I believe we can pass over the past of the live stock industry of the South; but we can say that the present is encouraging, and that the future seems bright. 


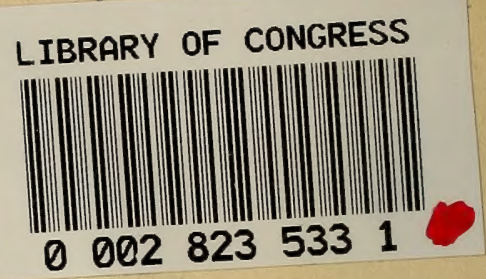



(

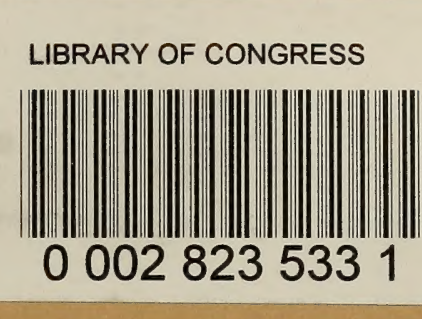

\section{Hollinger Corp. \\ pH 8.5} pH 8.5
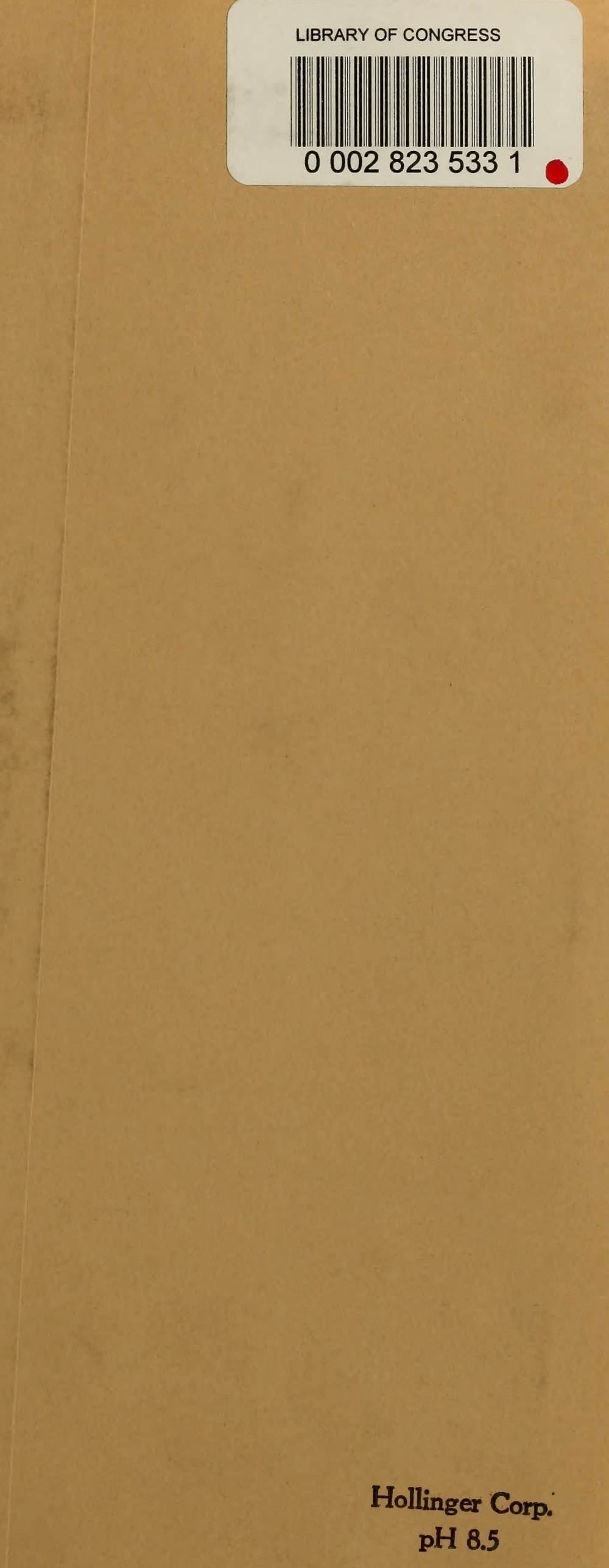

$$
\text { . }
$$




\section{LIBRARY OF CONGRESS}

||| || || || || || || || |||||||||||||||||||||| 00028235331

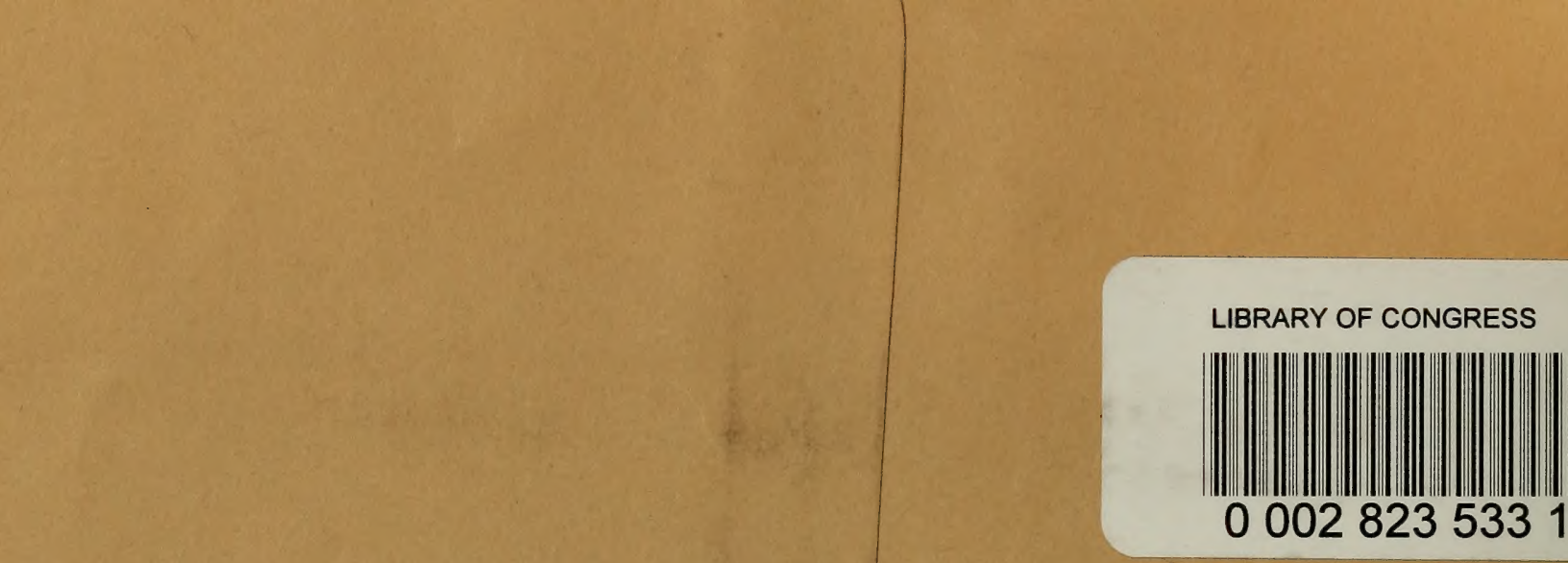

